\title{
Elite Women and the Agricultural Landscape, 1700-1830
}

Review Number: 2288

Publish date: Thursday, 25 October, 2018

Author: Briony McDonagh

ISBN: 978-1409456025

Date of Publication: 2018

Price: $£ 105.00$

Pages: 190pp.

Publisher: Routledge

Publisher url: https://www.routledge.com/Elite-Women-and-the-Agricultural-Landscape17001830/McDonagh/p/book/9781409456025

Place of Publication: London

Reviewer: Rachel Delman

Briony McDonagh estimates that over 10 per cent of land in Georgian Britain was owned by female landowners. Assuming her sample of 250,000 acres to be representative of broader patterns and trends, McDonagh surmises that 'somewhere in excess of 3 million acres in England were owned by women in the later eighteenth century and more than 6 million acres in Great Britain as a whole' (p. 27). Yet until now, the study of Georgian women's management and use of the British landscape has remained a surprisingly overlooked subject, owing to a prevailing tendency to see 18th-century landholding as an exclusively male world. In utilizing outdoor space for the exploration of women's lives and their gendered experiences of the world around them, McDonagh's rich and exciting new monograph makes a welcome contribution to the field of women's and gender history, whilst also greatly enriching our understanding of landscape, agriculture and property in Georgian England.

Together, the book's seven chapters explore the idea and reality of female landownership, covering everything from legal and practical aspects of estate management, to the moral economies of women's landownership and their posthumous commemoration as estate managers and improvers. McDonagh's corpus of evidence mainly comprises documentary sources of various kinds - estate records, family papers, wills and marriage settlements, deeds, parliamentary enclosure bills, acts and awards, estate and personal correspondence, diaries and memoirs, court records and newspapers - which she supplements with an analysis of non-textual sources, including maps and the landscape itself.

Chapter one, which functions as the introduction, deftly sets out the book's argument and methodological approach, and is impressive for its engagement with a thematically and chronologically wide-reaching historiography. Framing her work as an 'explicitly feminist historical geography of the eighteenth-century English rural landscape' (p. 2), McDonagh's primary aim is to challenge the traditional perception of the Georgian period as one in which women retired into domesticity. In this respect, her work belongs to a wider corpus of revisionist literature, which since the late 20th century has sought to complicate the long-held notion that pre-modern women were shut away or rendered passive by their associations with the domestic. What is new about McDonagh's contribution, however, is her decision to take the debate outdoors, and to explore and challenge the validity of the separate spheres model through a landscape approach. Indeed, she 
argues that despite a growing number of studies exploring aspects such as Georgian women's household management, their legal status as property owners and their roles as workers and the heads of business enterprises, little has been said about their contributions to estate management and improvement. In contrast, McDonagh highlights the more favourable state of medieval scholarship, where there has been surprisingly more discussion of women's estate management than for later, textually richer periods. Yet even for this period discussions of women and the land still have a way to go. Current studies remain largely descriptive, focused on single case studies, or confined to specialist journals, where they are not always given the recognition they deserve as part of the wider narrative of women's and gender history. In identifying a broad sample of female landowners and estate managers, and in utilizing outdoor space to explore the construction of elite femininities and masculinities, McDonagh presents the landscape as crucial for enhancing our understanding of gender, status and society in England, an approach which is not only pertinent to the Georgian period, but to pre-modern England more generally.

The book successfully balances wider observations on women's estate management and landownership with a nuanced reading of individual women's lives and experiences. Approximately 70 female landowners are brought to the fore, making this, as McDonagh herself identifies, the first large-scale quantitative study of female landownership in 18th- and 19th-century England (p. 25). The text explores how gentle and aristocratic women's experiences of landownership intersected with their social standing, marital status, geographical location and individual circumstances. The female landowners considered include single women, wives, widows, gentlewomen, aristocrats, young and old, mothers and childless women. All the women considered in the study are helpfully listed together in the appendix, along with their dates, ages on coming into property, routes to landownership, marital status whilst managing property, and years spent managing estates. Details of the women's husbands, children and maiden names are also provided, making this a highly useful tool for the reader in want of a point of comparison between the women included in the text.

McDonagh not only identifies the sheer scale of women's landownership in Georgian England, but also explores the ways in which gender roles and expectations were both formulated and reformulated through propertied women's estate management. This added layer of analysis is where the book's main strength lies. Throughout the text, McDonagh repeatedly rejects the commonplace assumption that 18th-century landholding was a 'man's world', along with the idea that women who managed estates were 'honorary men'. She does not argue, however, that estate management was conducted on gender neutral grounds; in fact, quite the opposite. McDonagh's example of a letter from Amabel Hume-Campbell, suo jure Countess De Grey (1751-1833) to her mother, cited in chapter six, beautifully illustrates this point. In the letter, HumeCampbell recounts how when walking the grounds of Wrest Park in Bedfordshire, she suddenly found herself sinking into a bog, with her escape attempt resulting in the loss of both her shoes. While the image of Hume-Campbell marching barefoot 'in the Stile of Jane Shore doing Penance' towards the Gamekeeper's lodgings is undoubtedly humorous, McDonagh uses the episode to make several important points about gender and women's estate management (p. 137). The first is that despite being a young woman and heiress, Hume-Campbell roams the landscape alone, freely crossing the boundary of the so-called 'feminine' space of the garden and entering into the 'masculine' realm of park and farmland without any seeming awareness of this presumed distinction. Secondly, McDonagh draws attention to the fact that although Hume-Campbell walks the estate with no apparent consciousness of gendered divisions of space, she nevertheless uses gendered language to recount the episode in her letter, describing her act of pushing branches aside as 'manly' (p. 137). Finally, McDonagh uses the countess's predicament to illustrate the impracticalities and restrictiveness of female clothing for women's perambulations of their estates, highlighting that HumeCampbell's experience of walking the grounds of Wrest was determined by the very clothes she wore, clothing which defined her gendered female body and placed very real restrictions on her actions. The significance of clothing in relation to gendered experiences of estate management finds further expression in one of the book's 17 images: a portrait of Henrietta Cavendish Harley, countess of Oxford and Mortimer (1694-1755). In the image, Cavendish Harley is depicted in a riding habit, her left hand on her hip, her right holding a whip and her steely gaze meeting the viewer's (p. 108). A playful mix of the masculine and the 
feminine, female riding garbs such as that worn by Cavendish Harley in her portrait had in the previous century attracted comment from Samuel Pepys, who in 1665 wrote that 'it was pretty to see the young pretty ladies dressed like men'. [1] [2] A year later, however, Pepys had changed his tune and had decided that women 'dressed in their riding garbs ... just for all the world like men ... was an odd sight', and one which did not please him.[2] [3] Gender, McDonagh argues, mattered. It shaped propertied women's lives and their experiences of owning, using and managing estate landscapes. In the book she shows that Georgian women's landownership and estate management was not straightforwardly feminine or masculine; rather, it was a complex interweaving of the two.

Following the introduction, chapter two, 'Women, land and property', addresses four key issues: the legal and marital status of female landowners; the scale of individual women's landholdings; the geographical distribution of female landownership; and change over time. In this chapter, McDonagh draws primarily on enclosure awards to explore single, widowed and married women's legal position as landholders, arguing that such records avoid the 'end of life' bias of the probate records and provide consistent information on acreage, to allow for cross-place and regional comparisons. While the increasing precedence of Common Law (in particular primogeniture and coverture) from the 16th century onwards curtailed married women's ability to secure and defend property, McDonagh identifies a gap between legal theory and lived experience. Married women and their families, she suggests, often exploited legal loopholes to their advantage and wives also frequently considered themselves landowners, even when the legal reality differed. For widows, too, it seems that there was a disjuncture between the theory and practice of jointure, with 'personalised arrangements highlighting the sheer diversity of widow's experiences' (p. 20). More generally, McDonagh argues that the shift from dower to jointure in the 16th century had far less of an impact on widows' landholdings than has usually been stated (p. 31). Here, she importantly situates her study of Georgian women within a wider historiography of women's landownership, thus highlighting the book's broader significance for those interested in women's experiences and practices of landholding beyond the chronological framework of Georgian England. The chapter then addresses the scale of women's landownership and the regional distribution of female-owned estates. McDonagh highlights that while for most women their experience was one of smallholding (just as it was for men), this is not to say that their landownership was insignificant, with more than one acre in ten owned by a woman in 18th- and 19thcentury England (p. 32). There were also regional differences in women's landownership, and McDonagh suggests that the proximity of counties such as Northamptonshire to London may have opened up more opportunities for propertied women than in the North where female landholdings were fewer in number ( $\mathrm{p}$. $30)$.

Chapter three, 'Managing the estate', marks a transition from theory to practice, to explore what women actually did with their land. This chapter offers a lively and dynamic picture of female account keeping and estate management, showing how many women actively participated in the more practical aspects, from walking the grounds of their estates, to auditing and sometimes even reorganising their accounts.

McDonagh's juxtaposition of the 'shaky' handwriting of Lady Elizabeth Dryden, a Northamptonshire widow, who had suffered a stroke, with 'the overly elaborate' hand of the teenage Elizabeth Hood (p. 41), not only personalises her prose, but also illustrates the wide range of women responsible for book keeping and the various points in the life course at which they did so. The relationship between propertied women and their estate stewards also surfaces as an important topic of discussion, with McDonagh convincingly making the case that although the division of labour obviously varied considerably, many women were highly involved in their affairs and were 'no less capable of decision-making and no more reliant on their stewards than male landowners' (p. 64). While married women's experiences of estate management are undoubtedly harder to recover, McDonagh also shows that many wives and mothers played key roles in the management of their natal and martial families' estates, often safeguarding lands for their sons during their minority.

Chapter four, 'Improving the estate', explores propertied women and parliamentary enclosure, and women's roles in both agricultural and non-agricultural improvements. Geography surfaces as an important variable, with the discussion of agriculture in the first half of the chapter taking the Midlands as its focus. 
Highlighting the example of Elizabeth Prowse (1733-1810), whose tenants at Wicken in Northamptonshire were described by one visitor to her estates in 1777 as 'the happiest set of peasants in England' (p. 84), McDonagh explores how women likely gained their knowledge of agricultural improvement through informal channels, such as their literary interests, visits to family estates and conversations with stewards, agents and peers. She identifies a number of women who wrote for the Annals of Agriculture, including Elizabeth Ilive (1769-1822), mistress of the third earl of Egremont, who conducted the potato trials at Petworth in Sussex between the births of her two children (p. 89). The second half of the chapter considers women's contribution to non-agricultural improvements, including coal mines, canals and other transport developments. Here, the well-known example of Anne Lister (1791-1840) of Shibden Hall in West Yorkshire, who played a key role in the industrial revolutions of northern England, proves instructive. An avid reader of geology books, Lister took an active interest in the management of her family's coal mines, recording her plans in her diary. She also assumed oversight of the pits belonging to her 'wife', Anne Walker, who was the co-heiress of a nearby mercantile family (p. 91). Overall, this chapter shows that through their activities, many women maintained and assisted the economic well-being of their families, with their actions importantly underpinning the interests of the Georgian gentry and aristocracy as a wider social group.

In 'Country houses, gardens and estate villages' (chapter five), McDonagh considers the long-held concept of the country house as a male status symbol, to explore what was unique or different about propertied women's estate management. Surveying the now abundant historiography on elite 'power houses', McDonagh indicates that little has been said on women's roles in building, remodelling and improving the country house and its wider estate. The first half of the chapter thus recovers a range of women responsible for large-scale building projects. Just as she addresses the division of responsibilities between the women and their stewards in chapter three, in this chapter McDonagh considers the often unclear line between architect and patron (p. 104). Although sometimes difficult to find, McDonagh highlights a number of women who are visible in the historical record as having commissioned large-scale building works, including the prolific builder, Frances Ingram, Viscountess Irwin (c.1734-1807), whose deliberate choice of a local architect likely enabled her to maintain greater control over her works at Temple Newsam in West Yorkshire (p. 104). Marriage, too, resurfaces as an important variable, which could both enable and curtail women's building activities (p. 106). While some women were able to collaborate or act independently of their husbands, others were only liberated through their widowhood. A discussion of women's commission of buildings on the wider estate, including schools and almshouses, leads on to the second half of the chapter, which considers the moral economy of women's estate management through their philanthropy. Here McDonagh considers how the feminised model of the charitable caregiver 'Lady Bountiful' afforded women a public role as figureheads in the community, whilst also providing a socially acceptable outlet through which to justify and demonstrate their 'right to rule' as landowners (p. 126). Lastly, the chapter engages in a discussion of politics, arguing that women utilized their positions to control the votes on their estates or to directly canvass for their preferred candidate. Although brief, this section importantly illustrates the wider resonances of women's domestic activities, thus adding a further nail in the coffin of the public/private binary. 
The final chapter before the book's conclusion, 'Representing women and property', explores the idea and image of the propertied woman in Georgian thought. Resting primarily on an analysis of letters, diaries, sermons and obituaries, the chapter considers the multiple contemporary discourses surrounding women and landownership. While McDonagh identifies a propensity for the literature of the period to link women's agency to their sexual looseness, she demonstrates that a number of women were able to circumvent these negative associations by presenting their estate management as a familial duty, integral to dynastic planning and motherhood. Similarly, she shows that in obituaries and death notices, women's contributions to estate economies (in the rare cases where they are mentioned) are framed in specifically feminised ways. Just as during life Lady Bountiful gave women a socially acceptable outlet for the enactment of their authority as local figureheads, so in death they were remembered as paragons of domestic virtue, and as daughters, wives and mothers.

The book's recent success in winning both the Joan Thirsk Memorial Prize and the Women's History Network Prize speaks of the magnitude of its contribution to both landscape studies and women's and gender history. While the Georgian period is well known as a time when the English landscape was reshaped through parliamentary enclosure, McDonagh's exploration of women's involvement in the process brings a new perspective to well-trodden ground. By recovering so many examples of propertied women, and by investigating the ways in which gender informed women's perceptions and practices of landownership, McDonagh also shows for the first time that Georgian women played a significant, yet hitherto unrecognised role in making the English landscape. In taking gender as a category of analysis and in exploring how women's estate management intersected with, upheld, and even challenged social norms of masculine and feminine behaviours, she convincingly argues that female landowners were not merely honorary men; rather, they created, managed and used landscapes on their own terms, and deserve to be recognised as such.

Notes

[1] [4] Samuel Pepys' Diary quoted in G. Stedman, Cultural Exchange in Seventeenth-Century France and England (Burlington, NJ, 2013), p. 170.

[2] [5] Ibid.

Source URL:https://reviews.history.ac.uk/review/2288

\section{Links}

[1] https://reviews.history.ac.uk/item/298091

[2] https://uolonline-

my.sharepoint.com/personal/danny_millum_sas_ac_uk/Documents/Reviews/current\%20reviews\%20for\%20editing/c [3] https://uolonline-

my.sharepoint.com/personal/danny_millum_sas_ac_uk/Documents/Reviews/current\%20reviews\%20for\%20editing/c [4] https://uolonline-

my.sharepoint.com/personal/danny_millum_sas_ac_uk/Documents/Reviews/current\%20reviews\%20for\%20editing/c

[5] https://uolonline-

my.sharepoint.com/personal/danny_millum_sas_ac_uk/Documents/Reviews/current\%20reviews\%20for\%20editing/c 